\title{
MENUNDA BERSUCI SEHABIS HAIDH DI KALANGAN MAHASISWI FAKULTAS SYARI'AH DAN EKONOMI ISLAM IAIN ANTASARI
}

\author{
Mashunah Hanafi \\ Fakultas Syariah dan Ekonomi Islam IAIN Antasari, Jl. Jenderal Ahmad Yani Km 4,5 Banjarmasin
}

\begin{abstract}
How if we postpone to purified when haidh has done. This paper will discuss about the reason of women students college who postpone their time to purified, and explore the Islamic view to responds this problem. This research find that the most of reasons of delay are: first, to make sure that their haidh are not exist anymore, and second, because they want to go to college. Based Islamic views, the reason to make sure whether haidhs blood completly stoped is permitted, but no more than one day. But, if the reason is to go to college, it is forbidden because it was included as negligence of shariah.
\end{abstract}

\begin{abstract}
Abstrak: Haidh adalah perkara yang fitrah bagi wanita, dan biasanya memiliki siklus tersendiri. Bagaimana apabila ketika sudah selesai haidhnya, tapi menunda untuk bersuci. Tulisan ini akan membahas tentang alasan dari beberapa mahasiswi yang menunda untuk bersuci, dan menjelaskan bagaimana pandangan Islam menyikapi masalah ini. Penelitian ini menemukan bahwa alasan penundaan yang ditemui diantaranya adalah karena untuk meyakinkan haidhnya sudah benar-benar berhenti karena jika tidak khawatir darah haidh akan keluar saat mereka pergi kuliah. Menurut pandangan Islam, jika alasannya adalah untuk meyakinkan bahwa darah haidh benar-benar sudah berhenti, maka penundaan diperbolehkan asal tidak lebih satu hari. Namun, jika alasan penundaan adalah karena ingin pergi kuliah, maka hal ini tidak dibenarkan dalam Islam, karena sudah termasuk melalaikan syariat.
\end{abstract}

Kata kunci: Haidh, bukum, adat, korelasi.

\section{Pendahuluan}

Haidh di dalam kalangan masyarakat dikenal dengan istilah "datang bulan", "dapat kain kotor" dan lain-lain. Dalam dunia kedokteran dinamakan menstruasi. Haidh dalam Islam berlaku sebagai penghalang dari ibadah-ibadah, seperti: shalat, puasa, masuk masjid, membaca dan menyentuh $\mathrm{Al}$ Qur'an, dan melakukan hubungan suami-istri. Bagi wanita yang sedang haidh, oleh syariah dilarang (haram) melakukan ibadah-ibadah seperti itu, walaupun ada diantaranya yang harus diqadha atau ditunda hingga memasuki masa suci.

Sehubungan dengan hal tersebut, jika darah haidh sudah habis keluar atau masa haid telah berakhir, maka diwajibkan untuk bersuci. Bersuci yang dimaksudkan di sini adalah bersuci yang bertujuan menghilangkan hadats besar, dalam hal ini adalah mandi (al Ghuslu). Al-Ghuslu (dengan fathah ghain atau dhammahnya) menurut istilah bahasa artinya mengalirkan air kepada sesuatu secara mutlak. Sedangkan pengertian menurut istilah syara' adalah mengalirkan air ke seluruh tubuh disertai dengan niat. ${ }^{1}$

Menurut syariah Islam, hal-hal yang memunculkan kewajiban mandi (dalam terminologi masyarakat umum disebut "mandi besar" atau "mandi junub") ada tiga perkara umum yang belaku baik atas kaum laki-laki maupun kaum wanita dan ada tiga perkara yang berlaku khusus bagi wanita. Perkara umum tersebut yaitu: pertama, seseorang diwajibkan mandi karena bertemunya dua hitan (kemaluan), yakni ketika masuknya ujung kemaluan atau dalam batas tertentu kepada farji, dan tidak berbeda apakah keluar mani atau tidak.

Firman Allah dalam surat Al- Maidah ayat 6:

$$
\text { وإن كنتم جنبا فاطهروا... (المائدة : (7) }
$$

"Dan jika kamu junub maka mandilah". ${ }^{2}$

\footnotetext{
1 Syekh Isa Asyur, Al Fiqhul Muyassar fil Ibadah, (DarulFikri, 1981) hlm. 45.

2 Dapertemen Agama RI., Al Qur'an dan'Terjemahnya, (Jakarta: Proyek Pengadaan Kitab Suci Al-Qur'an, 1997) hlm. 158.
} 
Hadits Abi Hurairah ra.:

$$
\begin{aligned}
& \text { حديث أجى هر يرة عن النبى صلى الله عليه وسلم قل : إذا } \\
& \text { جلس بين شعبها الأ ربع ثم جهدها فقد و جب الغسل الغسل أنزل } \\
& \text { أم لم ينزل. رواه أحمد ومسلم. }
\end{aligned}
$$

"Bahwa Rasul Saw telah bersabda : jika seseorang telah berada di antara anggotanya yang empat maksudnya kedua tangan dan kedua kaki isterinya lalu mencampurinya, maka wajiblah mandi, keluar mani ataupun tidak". (HR. Ahmad dan Muslim).

Kedua, seseorang diwajibkan mandi karena keluarnya mani berdasarkan sabda Nabi Saw:

$$
\text { إنما الماء من الماء. رواه مسلم.4 (HR. }
$$

"Sesungguhnya air itu disebutkan oleh air". (HR. Muslim).

Tidak ada perbedaan baik keluarnya pada waktu bangun atau tidur. Begitu pula dengan bersyahwat atau tidak, mengingat kemutlakan hadits tersebut.

Ketiga, seseorang diwajibkan mandi karena meninggal dunia. Hal ini berdasarkan sabda Nabi Saw orang ihram yang mati tertunduk oleh untanya :

$$
\text { أغسلوه بماء وسدر . رواه الشيخان. }
$$

"Mandikanlah ia dengan air dan daun bidara". (HR Syaikhani).

Adapun tiga perkara khusus bagi kaum wanita yang mewajibkan mandi adalah: pertama, mengalami Haidh. Hal ini berdasarkan firman Allah Swt dan hadits yang diriwayatkan Aisyah ra. :

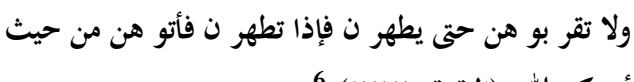

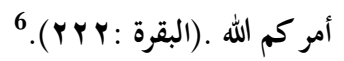

"Dan janganlah kamu mendekat isteri hingga mereka suci, jika ia telah suci maka datangilah dari mana saja seperti yang telah diperintahkan oleh Allah". 6

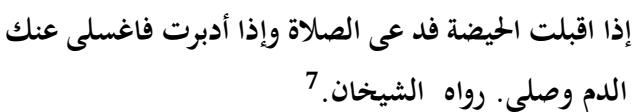

"Sesungguhnya Rasulullah Saw telah bersabda: Apabila telah tiba waktu haidh maka tinggalkanlah shalat dan apabila telah selesai

3 Muhammad Fuad Abdul Baqi, Al Lu' lu'walMarjan, (ArRiyadh: DaruIbniHuzaimah, 1414 H) jilid I, hlm.224

${ }^{4}$ Muhammad bin Ismail Al Kahlany Ash Shan'any, Sublus Salam, (Mesir :Musthafa Baby al Halaby, 1960) jilid, hlm. 148

Ibid.,jilid II, hlm.191

Dapertemen Agama RI., op.cit., hlm.54

Abul Husain Muslim bin Al Hajjaj bin Muslim Al Qusyairi An Nisaburi, Al Jami' us Shahih, (Beirut :DarulFikri, Tth.) Jilid I, hlm.180

\section{ketentuannya maka bersihkanlah darah dan} shalatlah."

Dijelaskan pula dalam hadits yang diriwayatkan Imam Bukhari :

\section{"Kemudian mandilah dan shalatlah."}

Kedua, seorang wanita diwajibkan mandi karena mengalami Nifas. Nifas adalah darah yang keluar dari kemaluan wanita yang disebabkan melahirkan, atau juga dapat dikatakan seperti haidh karena sesungguhnya ia adalah darah haidh yang terkumpul. Menurut ijma' para sahabat, nifas itu sama dengan haidh. ${ }^{9}$

Ketiga, seorang wanita diwajibkan mandi karena melahirkan walaupun hanya segumpal darah atau segumpal daging, karena wajib mandi itu ada dua sebab: 1) Bahwa melahirkan itu diduga keluar darah dan hukumnya tergantung pada yang diduganya. Seperti tidur sesungguhnya ia membatalkan wudhu sebab diduga telah berhadats. 2) Bahwa anak adalah mani yang terikat dari mani seorang wanita dan keluarnya mani adalah mewajibkan melaksanakan mandi. ${ }^{10}$

Dari penjelasan di atas, mengenai perkara yang mewajibkan seseorang mandi, yang menjadi titik berat dalam penelitian ini adalah masalah mandi sesudah haidh. Jika wanita menunda mandi (bersuci) sesudah haidh atau dengan kata lain tidak segera menghilangkan hadats besar, maka tertunda pulalah wanita tersebut mengerjakan ibadah yang seharusnya sudah dapat dikerjakan. Hal ini tentunya akan merugikan orang tersebut, karena kesempatan meraih ibadah ditinggalkan begitu saja.

Hasil penjelasan awal dalam diskusi kuliah fiqih Ibadah pada mahasiswa Fakultas Syari'ah IAIN Antasari, ada ungkapan-ungkapan yang dilontarkan mahasiswi yang terkadang menunda bersuci dari haidhnya dengan alasan yang bermacam-macam. Berdasarkan hasil pengamatan penulis dalam memberikan kuliah tersebut, menunda bersuci sehabis haidh itu ada pada kalangan mahasiswi Fakultas Syari'ah IAIN Antasari. Oleh sebab itu, penulis ingin meneliti lebih jauh dan mendalam, yang akan dituangkan dalam sebuah penelitian yang berjudul "MENUNDA

\footnotetext{
8 Imam Bukhari, Matan Shahih Bukhari, (Singapura: Maktabahwa Matba'ah Sulaiman Mar'ai, Tth) h.67

9 As SayyidSabiq, FiqhusSunnah, (Beirut :DarulFikri, 1983) jilid I, hlm.57

${ }^{10}$ Syekh Isa Asyur, op.cit., hlm. 46
} 
BERSUCI SEHABIS HAIDH (di kalangan Mahasiswi Fakultas Syari'ah dan Ekonomi Islam IAIN Antasari)".

\section{Pokok Permasalahan}

Berangkat dari latar belakang di atas, penelitian ini berusaha untuk mengkaji permasalahan yang dituangkan dalam bentuk pertanyaan penelitian "Bagaimana Menunda Bersuci Sehabis Haidh di kalangan Mahasiswi Fakultas Syari'ah dan Ekonomi Islam IAIN Antasari". Untuk lebih rincinya, penelitian ini akan mengkaji tiga hal yang meliputi :

1. Bagaimana gambaran haidh dan penundaan bersuci sehabis haidh bagi mahasiswi Fakultas Syari'ah.

2. Apa faktor dan akibat terjadinya penundaan bersuci sehabis haidh tersebut.

3. Bagaimana tinjauan hukum Islam dalam hal penundaan bersuci sehabis haidh tersebut.

\section{Metodologi Penelitian}

Penelitian ini dilakukan dengan menggunakan pendekatan kualitatif, dengan jenis penelitian lapangan (Field Research) yang bersifat studi kasus yaitu 5 (lima) kasus tentang menunda bersuci sehabis haidh di kalangan mahasiswi Fakultas Syari'ah dan Ekonomi Islam IAIN Antasari Banjarmasin.

Berbagai kajian literatur terutama kitab-kitab fiqih dimanfaatkan untuk kepentingan analisis. Berbagai literatur lain, misalnya kitab-kitab selain fiqih, hasil penelitian, digunakan sebagai bahan rujukan atau kepentingan analisis pendukung.

\section{Data dan Sumber Data}

Data yang digunakan dalam penelitian ini meliputi gambaran menunda bersuci sehabis haidh, apa yang dijadikan patokan dalam menentukan habisnya haidh itu, dan faktor-faktor yang menyebabkan terjadinya penundaan bersuci sehabis haidh tersebut. Sedangkan sumber data dalam penelitian ini adalah mahasiswi-mahasiswi Fakultas Syari'ah dan Ekonomi Islam IAIN Antasari Banjarmasin dan beberapa literatur yang berkaitan dengan masalah tersebut.

\section{Tinjauan Teori Dan Literatur Haidh}

Kata "haidh" adalah dari bahasa Arab yang menurut perubahan asal katanya berbunyi
Artinya identik dengan: سال - يسيل - سيلان - yaitu "mengalir" atau "membanjir". Oleh sebab itu dikatakan : untuk mengungkapkan bahwa "lembah itu penuh membanjir lalu mengalir". Adapun pengertian haidh (menstruasi) menurut istilah, para ulama mengemukakan definisi dan penjelasan yang saling melengkapi, diantaranya ialah sebagai berikut:

1. Dr. Wahbah Az Zuhaily, seorang ulama terkemuka dewasa ini memberikan definisi haidh sebagai berikut :

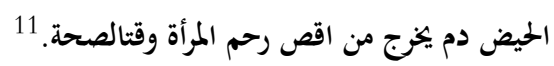

Haidh ialah: darah yang keluar dari puncak rahim kaum wanita pada waktu sehat.

2. Abul Hasan Al Bishry, seorang ulama yang terkenal, memberikan penjelasan yang berbunyi ;

3. "Sesungguhnya (haidh itu) darah yang keluar dari dalam rahim, yang dengan peristiwa pertamanya adalah seorang wanita sampai umur (baligh) dan haidh itu akan menjadi kebiasaan kaum wanita dari waktu ke waktu."

Ahmad Al Hushary, seorang Guru Besar di Al Azhar University memberikan keterangan sebagai berikut: "Dan di dalam kebiasaan pengertian syariat, haidh ialah nama bagi darah yang keluar dari rahim, yang tidak mengiringi peristiwa bersalin, yang dengan ukuran tertentu dalan suatu jangka waktu yang tertentu pula". Menurut Ensiklopedi Bahasa Arab, Al-Wasith, pengertian haidh itu ialah: "darah yang mengalir (keluar) dari dalam rahim kaum wanita pada hari hari yang tertentu setiap bulan". ${ }^{12}$

Dari penjelasan dan definisi di atas dapatlah ditarik beberapa unsur yang saling melengkapi untuk pengertian haidh, yaitu :

1. Haidh adalah nama bagi darah yang keluar dan berasal dari dalam rahim wanita yang sehat.

2. Haidh pertama adalah pertanda permulaan masa kedewasaan seorang wanita.

3. Peristiwa haidh adalah peristiwa yang mempunyai siklus kedatangan yang berulang dari waktu ke waktu.

\footnotetext{
11 Wahbah Az Zuhaili, Al Wasith fi Ushulul Fiqh Al Islamy, (Beirut : Darul Fikri, 1969) hlm. 183

12 Dr. Ibrahim Anis, et.al., alMu'jam al Wasith, (Mesir: Darul Ma’arif, 1972) jilid I, hlm. 212.
} 
4. Haidh bukanlah darah yang keluar dari rahim wanita seusai bersalin.

5. Peristiwa haidh biasanya terjadi secara berulang, selama beberapa hari setiap bulan

Oleh sebab itu dapatlah penulis simpulkan bahwa pengertian haidh ialah: "darah yang keluar dan berasal dari dalam rahim wanita yang sehat, lain dari kelanjutan peristiwa bersalin; kejadian pertamanya menjadi pertanda awal baligh (sampai umur) dan merupakan peristiwa kebiasaan atas kaum wanita secara berulang selama beberapa hari setiap bulan".

Uraian tentang haidh yang lebih luas dan terperinci menurut ilmu pengetahuan kebidanan dan kedokteran akan dapat ditelaah secara mendalam di dalam buku Ilmu kebidanan oleh S.A. Goelam, Arts dan Ilmu kebidanan oleh Prof. Dr. Sarwono Prawirohardjo, et.al. ${ }^{13}$

\section{Batas Usia Mulai Haidh}

Batas umur minimal seorang wanita mengeluarkan darah haidh adalah sembilan tahun. Apabila ada seorang wanita mengalami perdarahan sebelum usia tersebut, maka darahnya tersebut darah fasad (rusak) artinya sama sekali tidak ada kaitannya dengan hukum haidh. Hal ini berdasarkan penyelidikan Imam Syafi'I terhadap gadis-gadis Tihamah. ${ }^{14}$

\section{Lamanya Darah Haidh Keluar}

Para ulama berbeda pendapat mengenai masa terpendek dan terpanjang masa haidh seseorang wanita. Pendapat-pendapat para ulama tersebut antara lain:

1. Menurut Imam Malik, masa terpendek haidh tidak terbatas, sedangkan masa terpanjang adalah 15 hari.

2. Menurut Imam Hanafi, masa terpanjang adalah 10 hari dan masa terpendek adalah 3 hari.

3. Menurut Imam Syafi'i dan Hanabilah, masa terpendek adalah sehari semalam atau dapat juga disebut 24 jam, sedangkan masa terpanjang adalah 15 hari 15 malam. ${ }^{15}$

\footnotetext{
${ }^{13}$ Lihat: S.A. Goelam, Ilmu kebidanan, Yayasan Bina Pustaka, Jakarta, 1976, hlm. 33-38.

${ }^{14}$ Lihat: Kitab al Mubadzdzab, oleh Imam Abu Ishaq Asy Syarazi, hlm. 38.

${ }^{15}$ Lihat; Abul Walid Muhammad bin Ahmad Al Qurthuby, Bidayatul Mujtahid wa Nihayatul Muqtasid, Mushthafa
}

Imam Syafi'i menetapkan dalam kebanyakan kitab-kitabnya dan melajimkan (umumnya) masa haidh itu adalah enam atau tujuh hari, berdasarkan sabda Nabi Saw kepada Hahminah binti Jahsy:

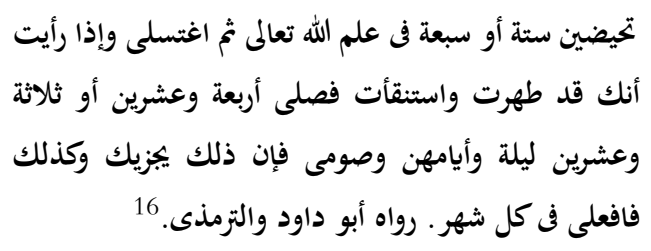

"Haidhlah kamu selama enam atau tujuh hari menurut ilmu Allah, kemudian mandilah kamu dan apabila kamu melihat bahwa kamu benarbenar suci dan bersih maka shalatlah selama dua puluh empat atau dua puluh tiga siang malam dan puasalah karena sesungguhnya yang demikian itu telah mencukupimu dan kerjakanlah setiap bulan”. (HR. Abu Daud dan Tarmidzi).

Berdasarkan hadits tersebut, pastikan haidh dan hukum ketetapannya berdasarkan pada apa yang diajarkan oleh Allah dan kebiasaan wanita yaitu enam atau tujuh hari.

\section{Masa-masa Suci}

Masa suci seorang wanita adalah hari-hari diluar masa haidh. Biasanya masa suci yang dialami oleh mayoritas kaum wanita adalah dua puluh tiga atau dua puluh empat hari ${ }^{17}$. Paling sedikitnya masa suci adalah lima belas hari dengan dasar atau dikarenakan apabila haidh itu lima belas hari. Pada masa-masa permulaan datangnya haidh, kadangkadang waktunya tidak teratur. Ada yang mengalami haidh satu kali (haidh pertama) dan pada bulan berikutnya tidak mendapatkannya sampai beberapa hari. Berikut beberapa karakteristik haidh yang perlu dipahami:

\section{Warna dan Sifat Darah Haidh}

Darah haidh mempunyai warna yang berbedabeda di samping sifatnya yang khas dan umum. Perbedaan warna itu dilihat ketika wanita itu di masa haidh, antara lain seperti hitam, merah, merah jambu, kuning, keruh, abu-abu seperti warna tanah.

Karena warna merah darah itu tidak hanya cukup satu saja, maka di sini akan dibedakan sebagai berikut:

al Baby al Halaby, Mesir, 1960, hlm. 50 .

16 Al Hafizh Ibnu Hajar Al Asqalany, Bulughul Maram min Adillatil Ahkam, (Mesir : Mushthafa Muhammad, 1352 H) hlm. 29.

${ }^{17}$ Asy Syekh Abu Yahya Zakaria Al Anshari, Fathul Wabhab, hlm. 26. 
1. Darah Qawi: yaitu darah yang paling kuat (paling tua), misalnya warna hitam lebih tua jika dibandingkan dengan warna merah.

2. Darah Dha'if: yaitu darah yang dilihat nampak lebih lemah dibandingkan dengan yang lainnya, misalnya warna merah lebih lemah warnanya kalau dibandingkan dengan warna hitam.

3. Darah $A d b$ 'af: yaitu darah yang dilihat lebih lemah dibandingkan dengan warna kedua warna di atas yaitu warna merah jambu lebih lemah dibandingkan dengan warna hitam dan merah.

Hal ini tidak menutup kemungkinan bahwasanya warna qawi itu hanya yang berwarna hitam saja, namun warna qawi itu bersifat nisbi (relatif) artinya melihat darah yang keluar itu apa jika berwarna merah jambu maka merah jambu ini lebih kuat jika dibandingkan dengan kuning, begitu seterusnya. Dengan demikian jika urutan secara kronologis antara darah qawi, darah dha'if dan darah adb'af sebagai berikut: ${ }^{18}$

1. Darah hitam lebih kuat bila dibandingkan dengan darah yang berwarna merah.

2. Darah yang berwarna merah lebih kuat bila dibandingkan dengan warna merah jambu.

3. Darah yang berwarna merah jambu lebih kuat bila dibandingkan dengan darah yang berwarna kuning.

4. Darah yang berwarna kuning lebih kuat jika dibandingkan dengan darah yang berwarna keruh.

Dengan demikian warna darah haidh mempunyai sifat sebagai berikut:

1. Hitam, berdasarkan hadits Fatimah binti Abi Hubaisy bahwasanya Rasulullah Saw bersabda:

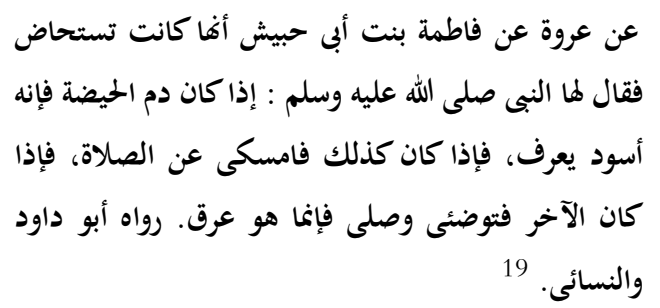

${ }^{18}$ Lihat Hasyiyah Bajerimi 'Alal Khatib hlm. 277.

19 Muhammad Ali bin Muhammad Asy Syaukani, Nailul Authar, (Mesir : Mushthafa al Baby al Halaby, Tth) juz I, hlm. 318.
"Dari Urwah dari Fatimah binti Abi Hubaisy, sesungguhnya beristihadhah, lalu Nabi Saw bersabda kepadanya: "kalau benar darah itu darah haidh, maka warnanya adalah hitam sebagaimana sudah dikenal, lalu apabila ia benar demikian keadaanya, maka tinggalkanlah sholat, akan tetapi jika berwarna lain, maka berwudhulah dan sholatlah, karena sesungguh nya tidak lain ia adalah basah-basah". (HR. Abu Daud dan Al Nasa'i).

2. Merah, karena sesungguhnya ia adalah merupakan warna asal darah.

3. Kuning dan ia adalah air seperti nanah yang memancar kekuningan.

4. Kotor/keruh ia adalah antara putih dan hitam air keruh.

Imam Asy Syaukani menyatakan bahwa darah haidh diketahui dengan sifatnya, jika darahnya berwarna hitam, ia adalah darah haidh, kalau lain maka ia adalah darah istihadhah ${ }^{20}$. Adapun warna kuning, yaitu seperti nanah berwarna kuning, warna keruh seperti air keruh, warna abu-abu seperti warna tanah. Dalam hal ini para imam mazhab berselisih tentang warna tersebut. Hanifah dan Syafi'iyah mengatakan, ia adalah haidh jika keluar pada hari haidh, yaitu sepuluh hari menurut Hanafiah dan lima belas hari menurut Syafi'iyah. Menurut Malikiyah, ia adalah haidh pada hari kebiasaannya dan tiga hari sesudahnya untuk membersihkan diri. Menurut Hanabilah, ia adalah haidh pada hari kebiasaan dan tidak diperhitungkan diluar hari kebiasaan. Abu Yusuf menyatakan, warna keruh tidak dianggap haidh, kecuali sesudah keluarnya darah. Sedangkan Ibnu Hazm, Ats Tsauri dan Al Huza'iy menegaskan bahwa warna keruh dan kuning bukanlah haidh sama sekali.

Selanjutnya, ada satu hadits yang menjelaskan apabila sepotong kapas yang putih maka janganlah diperhitungkan sebagai haidh berdasarkan hadits Murjannah budak Aisyah RA ia berkata:

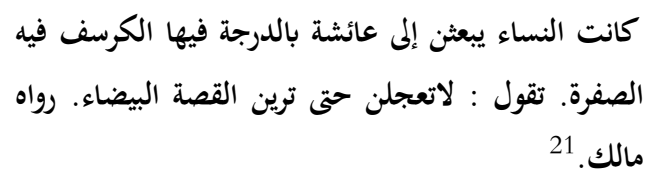

"Ada beberapa wanita yang mengutus kepada Aisyah RA dengan membawa pembalut didalamnya terdapat kapas yang masih kuning, maka Aisyah berkata ; janganlah kamu sekalian

\footnotetext{
20 Ibid., hlm. 406.

${ }^{21}$ Syekh Ahmad Isa Asyur, Al Fiqhul Muyassar fil Ibadah, (Darul Fikri, 1981) hlm. 85.
} 
tergesa-gesa sehingga kamu melihat sepotong kapas yang putih". (HR. Malik).

Yang dimaksud adalah sepotong kapas diletakkan pada farji untuk mengetahui bekas haidhnya, maka apabila dikeluarkan tetap putih berarti tanda suci.

\section{Larangan Bagi Wanita yang Sedang Haidh}

Wanita yang berhaidh dan nifas berserikat dengan orang yang junub mengenai semua hal yang terlarang bagi mereka. ${ }^{22}$

1. Mengerjakan shalat, baik shalat fardhu ataupun shalat sunat.

Rasulullah bersabda:

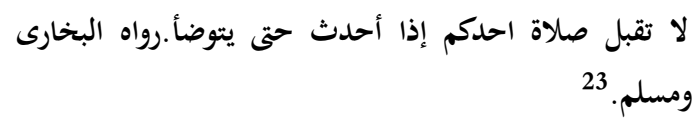

"Tidak diterima shalat seseorang diantaramu apabila berhadats sebelum berwudhu”. (HR. Bukhari Muslim).

2. Mengerjakan puasa, baik puasa fardhu maupun puasa sunat.

Hal ini berdasarkan hadits yang diriwayatkan oleh Abu Sa'id Al Khudry RA dimana Rasulullah Saw bersabda :

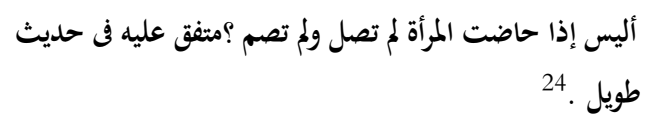

Bukanlah wanita itu apabila ia berhaidh maka ia tidak bershalat dan tidak berpuasa? (HR. Bukhari dan Muslim di hadits yang panjang).

3. Mengerjakan thawaf

Hal ini berdasarkan hadits yang berasal dari Aisyah RA dimana beliau bersabda :

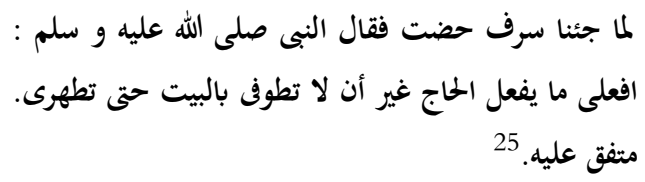

"Tatkala kami telah mendatangi (kampung) Sarif akupun berhaidh, maka berkata Nabi Saw (kepadaku): lakukanlah apa-apa yang dilakukan oleh seseorang yang berhaji, hanya saja

\footnotetext{
22 As Sayyid Sabiq, Fiqhus Sunnah, (Beirut: Darul Kitab Al Araby, 1973) jilid I, hlm. 85.

${ }^{23}$ Abul Husain Muslim bin Al Hajjaj bin Muslim Al Qusyairi An Nisaburi, AjJami'us Shabih, (Beirut : Darul Fikri, Tth) jilid I, hlm. 140-141.

${ }^{24}$ Al Hafizh Ibnu Hajar Al Asqalany, op.cit., hlm. 30.

${ }^{25}$ Muhammad bin Ismail Ash Shan'any, Subulus Salam, (Mesir: Musthafa al Baby al Halaby, 1960) jilid I, hlm. 190.
}

janganlah engkau berthawaf sekeliling Baitullah hingga engkau suci”. (HR. Bukhari dan Muslim)

4. Membaca Al Qur'an, baik sedikit maupun banyak. Hal ini berdasarkan hadits Rasulullah Saw :

$$
\begin{aligned}
& \text { لا يقرأ الجنب ولا الحائض شيئا من القرآن.رواه الترمذى وأبو } \\
& \text { داود وابن ماجه. }
\end{aligned}
$$

"Tidak boleh bagi orang junub dan orang haidh membaca sesuatu daripada Al Qur'an”. (HR. Turmudzi, abu Daud dan Ibnu Majah)

5. Menyentuh mushhaf / al Qur'an, mengangkat/ membawa al Qur'an, kecuali jika dalam keadaan terpaksa dan menjaga atau memelihara dari bahaya.

Terdapat hadits Rasulullah yang diceritakan dari Abu Bakar bin Muhammad yang mengatakan sebagai berikut :

$$
\begin{aligned}
& \text { أن النبى صلى الله عليه وسلم كتب إلى أهل اليمن كتابا و }
\end{aligned}
$$

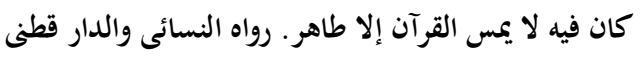

$$
\begin{aligned}
& \text { والبيهقى . }
\end{aligned}
$$

"Bahwa Nabi Saw telah berkirim surat kepada penduduk Yaman, didalamnya disebut: "tidak dibolehkan menyentuh Al Qur'an kecuali orang yang suci".

6. Beri'tikaf / menetap di Mesjid

Di dalam perkara beri'tikaf, para ulama berbeda pendapat sebagai berikut: Golongan Maliky berpendapat bahwa peristiwa junub yang mencakup juga persoalan haidh adalah merupakan penghalang mutlak untuk memasuki mesjid, apalagi beri'tikaf. Golongan yang kedua, diantaranya termasuk golongan Asy Syafi'iyah berpendapat bahwa junub dan haidh adalah penghalang untuk beri'tikaf, akan tetapi tidak merupakan penghalang kalau hanya sekedar masuk untuk lewat saja. Golongan yang ketiga, yaitu aliran Daud Azh Zhahiry memandang bahwa junub maupun haidh secara mutlak tidak merupakan halangan untuk masuk dan tinggal beberapa waktu di dalam mesjid ${ }^{28}$. Hal tersebut berdasarkan firman Allah Swt :

${ }^{26}$ Abdul Wahab Abdul Lathif, Mukhtarat al Ahadits wal Hikam an Nabawiyyah, (Mesir: Isa al Baby al Halaby, 1378 H) hlm. 152.

27 As Sayyid Sabiq, op.cit., hlm. 49.

${ }^{28}$ Abdul Walid Muhammad bin Ahmad bin Rusyd Al Qurthuby, Bidayatul Mujtahid wa Nihayatul Muqtashid, (Mesir : Mushthafa al Baby al Halaby, 1960) hlm. 48-49. 


\section{ولا جنبا إلا عابرى سبيل حتى تغتسلوا ـ (النساء : 1643)}

“Janganlah kamu hampiri mesjid sedangkan kamu dalam keadaan junub, terkecuali sejedar berlalu saja hingga kamu mandi". ${ }^{29}$

Selain itu terdapat hadits Rasulullah Saw yang diriwayatkan oleh Abu Daud dan dinilai shahih oleh Ibnu Khuzaimah, dimana Rasulullah Saw bersabda:

$$
\text { إنى لا أحل المسجد لحائض ولا جنب.30 }
$$

"Sesungguhnya aku tidak menghalalkan mesjid itu bagi (wanita) yang haidh dan (orang) yang junub”.

7. Melakukan hubungan sebadan (wath'i)

Asy Syekh Mahmud Khattab As Subhi mengatakan bahwa jumhur ulama berpendapat diharamkan bergaul dengan isteri ketika berhenti darah haidhnya, sebelum mandi walaupun setelah batas maksimal. Ahli fiqih pengikut Hanafi berpendapat, apabila lewat batas maksimal bagi wanita yang haidh (yaitu sepuluh hari) maka boleh menggaulinya sebelum darah berhenti dan mandi, tetapi sangat dianjurkan mandi sebelum meng-gaulinya.

Dari pendapat di atas dapat dikatakan bahwa apabila darah terhenti tepat pada kebiasaannya sebelum masa terbanyak, tidak boleh menggaulinya sebelum ia mandi atau bertayammum dan lebih hati-hati ialah tidak mendekati wanita haidh, kecuali setelah mandi, meskipun berhenti darah haidhnya setelah masa terbanyak.

Firman Allah Swt :

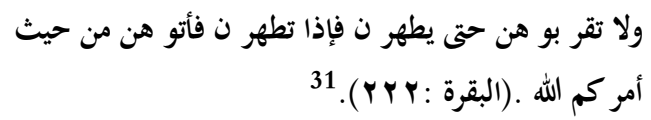

"Dan janganlah engkau dekati mereka, sehingga mereka suci maka gaulilah mereka menurut apa yang diperintahkan oleh Allah. Sesungguhnya Allah menyukai orang-orang yang bertaubat dan menyukai orang-orang yang bersuci”. ${ }^{32}$

\section{Mandi (Bersuci) Sesudah Habis Haidh}

Mandi merupakan salah satu bentuk kegiatan yang biasa dilakukan oleh hampir setiap manusia,

${ }^{29}$ Departemen Agama RI., Al Qur'an dan Terjemahnya, (Jakarta : Proyek Pengadaan Kitab Suci Al Qur'an, 1979) hlm. 125.

${ }^{30}$ Al Hafizh Ibnu Hajar Al Asqalany, op.cit., hlm. 25.

31 Dapertemen Agama RI., op.cit., hlm.54

${ }^{32}$ Departemen Agama RI., op.cit., hlm. 54. sebab disamping mempunyai fungsi membersihkan badan juga banyak mengandung segi-segi positif bila ditinjau dari segi kesehatan, namun kebanyakan kita tidak dapat mengungkapkan rahasianya secara menyeluruh. Tetapi yang jelas dan sering kita alami bahwa apabila badan itu kita guyur dengan air yang sejuk, maka badan dan otot-otot yang tadinya lemas tenaganya menjadi pulih kembali.

Kalau kita tinjau dari sudut pandang agama, mandi itu menjadi bermacam-macam tergantung pada niyatnya orang yang bersangkutan, secara garis besar dan menurut ketentuan mandi itu ada tiga: 1) Mandi wajib, 2) Mandi sunnat, dan 3) Mandi biasa (mubah) yakni mandi yang sekedar untuk menghangatkan tubuh atau mendinginkan atau hanya sekedar untuk membersihkan kotoran dan bau badan. Adapun hal-hal yang diwajibkan untuk mandi ada enam perkara, tiga perkara wajib atas kaum laki-laki sekaligus wanita dan tiga perkara khusus bagi wanita. (Hal tersebut telah diuraikan secara lengkap dalam latar belakang laporan penelitian ini).

Salah satu dari enam perkara tersebut adalah bersuci bagi wanita sehabis haidh. Wanita yang akan melakukan hal-hal terlarang bagi wanita haidh diwajibkan bersuci (mandi wajib) setelah haidhnya habis. Sebagai dasar hukum dari wajibnya mandi sehabis haidh antara lain sebagai berikut:

Hadits dari Aisyah RA Rasulullah bersabda

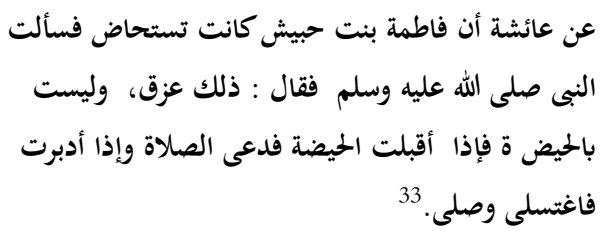

"Dari Aisyah, Bahwa Fatimah binti Hubaisy sedang istihadhah, lalu aku bertanya kepada Nabi Saw, kemudian ia menjawab : itu hanya sebagai peluh, dan bukan haidh maka apabila engkau sedang haidh maka tinggalkanlah shalat dan kalau telah selesai maka mandilah dan shalatlah”. (HR. Muslim).

Hadits dari Aisyah RA diriwayatkan bahwa Rasulullah Saw telah bersabda:

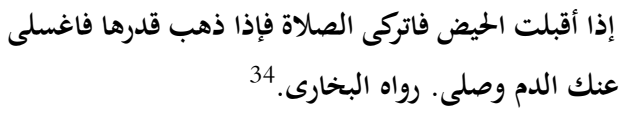

33 Abdul Husain Muslim bin Al Hajjaj bin Muslim Al Qusyairy An Naisabury, op.cit., hlm. 180.

${ }^{34}$ Imam Al Bukhary, Matan AlBukhary, (Semarang: Thoha Putra, 1981) jilid I, hlm. 79. 
"Bila haidh datang, maka tinggalkanlah shalat dan apabila telah hilang kadarnya, maka cucilah darah daripadamu dan kemudian mandi dan shalatlah”. (HR. Bukhari)

Hadits riwayat Turmidzi dan Ad Daru Quthny:

$$
\begin{aligned}
& \text { الطواف صلاة إلا أن الله أحل فيه الكلام فمن تكلم فلا } \\
& \text { تكلم إلا بخير. رواه الترمذى والدار قطنى. } 35
\end{aligned}
$$

"Thawaf itu merupakan shalat, hanya saja Allah halalkan padanya bercakap-cakap, maka barang siapa yang bercakap-cakap hendaklah mengenai yang baik-baik". (HR. Turmudzi dan Ad Daru Quthny)

Adapun mandi wajib tersebut mempunyai dua rukun atau fardhu. Yang pertama niat, berdasarkan sabda Nabi Saw :

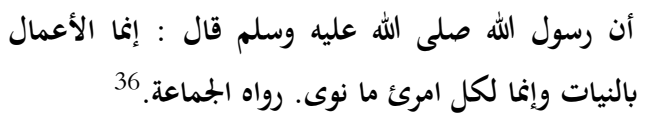

"Bahwa Rasulullah Saw bersabda: semua perbuatan itu adalah dengan niat, dan setiap manusia akan mendapat sekedar apa yang diniatkannya". Tempatnya niat adalah di dalam hati dan dilakukan bersamaan pertama kali membasuh bagian badan. Sahnya mandi disyaratkan dengan mendahulukan menghilangkan najis dari badan.

Kedua, menyiram air sampai dasar tumbuhnya rambut dan seluruh badan, dalam sebuah pengertian hadits disebutkan, di bawah tiap-tiap pangkal rambut dan bersihkanlah badan.

Hadits Rasulullah Saw yang diriwayatkan dari Ummi Salamah :

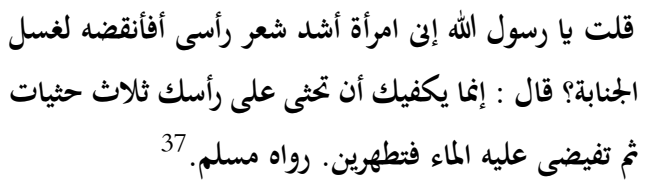

"Wahai Rasulullah, sesungguhnya aku adalah wanita yang sangat banyak rambut, apakah aku harus melepaskan rambut untuk mandi junub? Beliau menjawab : Sesungguhnya cukup bagimu dengan menyiramkan air dengan kedua belah tanganmu tiga kali lantas tuangkan air atasnya maka kamu telah suci.” (HR. Muslim)

Tercakup didalamnya rambut yang jarang, sedang rambut yang banyak itu tidak menghalangi sampainya air pada kulit dan pangkalnya. Adapun

\footnotetext{
35 As Sayyid Sabiq, op.cit., hlm. 588.

${ }^{36}$ Ibid., hlm. 38.

37 Abul Husain Muslim bin Al Hajjaj bin Muslim Al Qusyairy An Naisabury, op.cit., hlm. 178.
}

keseluruhan badan adalah kulit, maka wajib membasuh segala yang nampak darinya sampai pada lubang kedua telinga yang nampak dan lipatanlipatan badan, misalnya bagi wanita yang nampak pada waktu duduk menunaikan hajat. Juga wajib menghilangkan kotoran-kotoran yang terdapat di atas kuku-kuku karena ia adalah penghalang sampainya air pada kulit.

\section{Isi dan Pembahasan \\ Gambaran Terjadinya Haidh}

Responden pertama M NIM 9211113746. Terjadinya haid pertama pada umur 13 tahun. Dari haidh pertama sampai sekarang mengalami haidh yang rutin setiap bulan, dan waktunya senantiasa mengalami penanggalan mundur dari tanggal bulan yang sebelumnya. Kemunduran itu antara dua sampai empat hari. Sebelum keluarnya darah haidh mengalami sakit perut dan pinggang selama satu atau dua hari. Waktu keluar darah haidh yang agak deras adalah empat hari dan seterusnya agak sedikit, dan warna darahnya memudar.

Lama haidhnya tujuh hari, pada hari ke lima haid kadang-kadang darahnya habis, baik yang berwarna kuning ataupun keruh, akan tetapi $\mathrm{M}$ tidak langsung bersuci tetapi senantiasa menunggu sampai dua hari, hal ini dilakukan karena untuk meyakinkan apakah benar darah haidhnya sudah habis. Karena pernah terjadi yang diperkirakan sudah habis dalam lima hari lalu dia bersuci, tetapi ternyata darah haidhnya keluar lagi dengan warna agak keruh, hal ini terjadi tidak setiap bulan. Tetapi kalau ternyata selama dua hari menunggu itu darah kuning ataupun keruh itu tidak keluar barulah $\mathrm{M}$ mandi, ini terjadi pada hari ke delapan. Kalau hal tersebut terjadi maka selama dua hari itu ia tidak melaksanakan ibadah yang terkait dengan ibadah yang terlarang di lakukan bagi orang haidh, misalnya saja ia tidak shalat, dan tidak pula ia pernah mengqadanya.

Responden kedua bernama Z NIM 9411218470. Z mengalami haidh pertama pada saat berumur 13 tahun hingga sampai sekarang berumur 22 tahun, kedatangan haidhnya terus menerus setiap bulan tanpa pernah tertunda atau berhenti. Lama terjadinya haidh bagi $Z$ adalah selama 11 atau 12 hari, hal ini sudah termasuk penundaan bersuci (mandi) selama dua hari. Penundaan ini dilakukan Z karena untuk meyakinkan apakah benar-benar haidhnya sudah habis. $Z$ mengetahui habisnya haidh itu dengan mengambil kapas yang disapukan 
pada farji. Kalau memang tidak ada bekas apa-apa, maka itu dianggap benar-benar suci.

Masa sucinya antara dua kali haidh itu hanya sekitar 15 atau 16 hari saja bahkan kadang-kadang kurang dari 15 hari, kalau hal ini terjadi maka Z menganggapnya sebagai istihadhah beberapa hari sebelum sampai jarak dua kali siklus itu 15 hari.Selama haidh pertama sampai sekarang hanya pernah dua kali haidh saja yang jaraknya itu dianggap normal yaitu sama tanggal kedatangan haidh dengan bulan yang sebelumnya. Pada waktu haidh, perut tidak terasa sakit tetapi sebelum haidh itu keluar ada terasa sakit, dua hari pertama waktu haidh itu darahnya hanya sedikit dan pada hari ketiga sampai hari kelima darah haidh banyak, dengan warna merah kehitam-hitaman.

Responden ketiga bernama Um NIM 9211113606. Terjadinya haidh pertama pada umur 15 tahun, dari haidh pertama terjadi, tidak pernah berhenti / rutin dating setiap bulan, dan waktunya tidak menentu, pernah maju dan pernah mundur dari tanggal kedatangan haidh bulan yang sebelumnya. Maju mundurnya sangat tergantung dengan makanan yang dimakan seperti kalau sering makan buah nenas maka keluarnya darah haidh itu bisa lebih cepat. Sebelum haidh itu dating pernah mengalami sakit perut selama satu atau dua hari.

Lama haidhnya tujuh hari, pada hari ke enam haidhnya sudah habis, tetapi Um tidak langsung mandi atau bersuci karena Um melakukan ini untuk meyakinkan apakah darah haidhnya benar-benar sudah habis bahkan pernah pula dia menunda bersucinya karena rumahnya dengan kampus sangat berjauhan sedangkan kuliah dimulai pukul 07.00 pagi maka tidak sempat Um mandi wajib pagi itu, maka ditundanyalah sampai tengah hari sesudah pulang dari kuliah.

Akan tetapi kalau bulan Ramadhan Um pada hari kelima dia sudah mandi/bersuci, tapi kalau ternyata darah kuningnya keluar lagi, sesudah habisnya mandi lagi, alasanya dia mau cepat-cepat puasa. Um mengetahui habisnya haidh itu berdasarkan darah, jika darah warna keruhnya tidak ada lagi maka bersucilah dia, hal ini sudah termasuk menunggu 1 hari.

Responden keempat bernama N, NIM 9411218527. Terjadinya haidh pertama pada saat berumur 12 tahun. Setelah haidh pertama datang, tidak pernah haidh lagi selama tujuh bulan. Kemudian pada bulan kedelapan baru haidh lagi sampai sekarang rutin setiap bulan. Sebelum atau sesudah keluarnya darah haidh ia tidak pernah mengalami sakit.

Lama haidhnya adalah tujuh hari dengan tiga hari pertama keluarnya banyak kemudian hari keempat sudah sedikit dan warna darahnya sudah memudar, hari keenam sudah tidak keluar lagi, tetapi $\mathrm{N}$ tidak langsung bersuci, dia membiarkan dahulu sehari semalam baru $\mathrm{N}$ mandi dengan alasan kalau ada keluar lagi, jadi dia belum yakin kalau darah itu sudah habis. Dalam penundaan tersebut kalau ternyata darah itu tidak keluar, maka ia mengqada shalat yang tertinggal tersebut. N mengetahui habis haidhnya dengan melihat warna dari darah tersebut. Kalau masih keruh maka itu dianggap haidh tapi kalau berwarna putih maka itu bukan haidh.

Responden ke lima bernama NT NIM 9701111872. Haidh pertamanya terjadi pada umur 12 tahun. Dari haidh pertama sampai sekrang mengalami haidh yang setiap bulan, dan waktu datangnya tidak teratur kadang-kadang maju, kadang-kadang mundur. Hal ini bisa terjadi maju kalau sering makan rujak (nenas) dan juga apabila minum es. Waktu keluar darah haidh, darahnya langsung keluar banyak (deras) selama duahari, pada saat itu pula perut baru terasa sakit.

Lama haidhnya enam hari, pada hari ke lima haidhnya sudah berhenti baik darah keruh maupun agak kuning, akan tetapi NT tidak langsung bersuci, tetapi dia membiarkannya dahulu selama satu hari, NT khawatir kalau darah itu kelaur lagi dan pernah pula NT menunda mandi yang seharusnya dia mandi pagi tetapi dilaksanakanya tengah hari, hal ini karena dia takut tidak sempat kuliah. Akibatnya dia tidak sempat melaksanakan shalat beberapa waktu.

\section{Gambaran Penundaan Bersuci Sehabis Haidh}

Dari uraian sebelumnya dapat dipahami bahwa batas usia mulai haidh adalah sembilan tahun. Batas umur sebanyak-banyaknya tidak ada, sebab mungkin ada wanita yang selama hidupnya tidak pernah haidh. Anak gadis mulai mengeluarkan darah haidh, tidak sama satu dengan yang lainya, ada kalanya cepat dan ada kalanya lambat. Biasanya berkisar sembilan tahun Qamariah Taqririyah (menurut tanggal rembulan). Di Indonesia yang beriklim tropis, kebanyakan gadis memulai haidhnya sekitar umur 13-15 tahun. 
Hasil penelitian dari lima responden yang ditemui penulis ada dua responden yang berumur 13 tahun, dua orang yang berumur 12 tahun dan satu orang yang berumur 15 tahun. Berdasarkan keterangan di atas dapat diambil suatu kesimpulan atau setidak-tidaknya suatu pandangan bahwa cepat atau lambatnya anak gadis mengeluarkan darah haidh sangatlah dipengaruhi oleh beberapa faktor antara lain adalah:

1. Keturunan: Seorang wanita karena kebiasaan orang tua mereka cepat mengeluarkan darah haidh maka kebanyakan anak-anaknya juga akan mengalami haidh agak cepat.

2. Makanan : Makanan sangat mempengaruhi proses terbentuknya darah haidh.

Sebab dengan gizi yang tinggi yang banyak mengandung zat harmonal maka akan cepat menunjang kesuburan badan, dan dengan suburnya badan, seseorang akan cepat mengalami proses kematangan.

3. Iklim : Iklim juga sangat berpengaruh, sebab telah kita ketahui wanita-wanita Arab akan berbeda sekali dengan wanita-wanita Indonesia, bahkan penyelidikan Imam Syafi'i justru mengatakan wanita-wanita Thihamah baru berumur 9 tahun sudah mengalami haidh, sedangkan umur 9 tahun jarang sekali kita jumpai pada wanita-wanita Indonesia.

4. Lingkungan

Seorang wanita yang karena lingkungan-nya dimana kegiatan olahraga (misalnya) tidak ditemukan, danmereka hanya melakukan pekerjaan ringan yang tidak banyak bergerak, tentunya akan lain dengan wanita-wanita yang hidup leluasa berolahraga secara bebas. Sebab bagi wanita yang kurang bergerak, konsumsi makanan diserap tubuhnya akan lebih banyak ke arah proses pembuatan selsel telur. Berbeda dengan wanita-wanita yang aktif olahraga, maka konsumsi makanan yang mereka serap disalurkan ke anggota tubuh untuk mengganti zat-zat dan sari makanan yang telah diserap.

Dengan demikian ada perbedaan mendasar antara mereka yang ada di suatu lingkungan tertentu. Adapun lamanya darah haidh itu keluar, dari hasil penelitian yang ditemukan ada 3 orang responden yang tujuh hari dan satu orang yang enam hari dan satu orang yang 11 hari. Hal ini sebenarnya akan sangat menarik manakala dikaitkan dengan hadits Rasulullah Saw kepada Lahminah binti Jahsy, seorang wanita yang mengalami haidh yang banyak mengeluarkan darah serta lama pula masanya sehingga sampai kepada istihadhah. Rasulullah Saw bersabda seakan-akan menggambarkan kepadanya bagai-mana kebiasaan lamanya kebanyakan kaum wanita berhaidh yaitu:

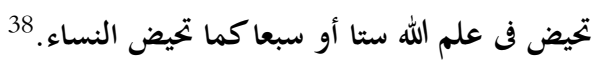

"Berhaidhlah engkau - di dalam ilmu Allah enam atau tujuh (hari) sebagaimana halnya kaum wanita berhaidh pada setiap bulan."

Hadits tersebut telah ditulis secara lengkap pada bab II dari hasil penelitian ini. Walaupun demikian penulis pun menyadari bahwa untuk mengetahui secara lebih umum dan lebih teliti dan pasti, akan awal waktu haidh dan jangka waktu lamanya haidh yang dialami kaum wanita di daerah ini pada khususnya, tentu saja menghendaki penelitian tersendiri dan secara khusus pula.

Di samping itu semua maka menurut hemat penulis bahwa yang terpenting untuk diperha-tikan di dalam masalah jangka waktu lamanya haidh itu ialah: Pertama, bahwa wanita yang mempunyai "kebiasaan tetap" dalam hal jangka waktu lama haidhnya hendaklah berpegang atau berpedoman kepada kebiasaannya yang tetap itu. Hal ini beralasan dengan hadits Ummi Salamah RA yang menerangkan bahwa beliau pernah bertanya kepada Rasulullah mengenai seorang wanita yang berpenyakit selalu banyak dan lama keluar darah, maka Rasulullah lalu berkata :

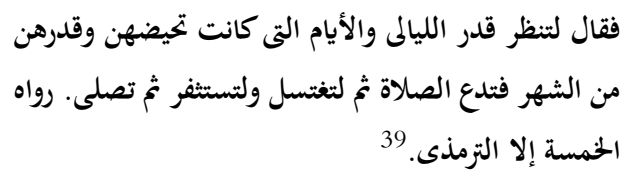

"Maka bersabdalah Rasulullah Saw, hendaklah (wanita itu) memperhatikan kadar (bilangan) malam dan hari yang biasanya ia berhaidh dalam setiap bulan. Maka sebab itu hendaklah ia meninggalkan shalat, kemudian hendaklah ia mandi dan menutupi kemaluannya dengan seumpama kapas, lalu (melaksanakan) shalat. (HR. Ahmad, Abu Daud, An Nasa'I dan Ibnu Majah).

38 Abu Bakar Ahmad Al Jashshash, Ahkamul Qur'an, (Cairo : Darul Mush-haf, Tth) jilid II, hlm. 24.

39 As Sayyid Sabiq, Fiqhus Sunnah, (Beirut : Darul Kitab al Araby, 1973) jilid I, hlm. 72 - 73. 
Kedua, bahwa wanita yang tidak mempunyai "kebiasaan tetap" dalam hal jangka waktu lama haidhnya hendaklah berpedoman kepada ciri-ciri khas keadaan (warna) darah haidh, yang sebenarnya memang lumrah dikenal oleh kalangan kaum wanita, hal ini beralasan kepada hadits tentang Fathimah binti Abi Hubaisy yang berasal dari Aisyah RA (yang telah disebutkan dalam bab II).

Ketiga, bahwa wanita yang mempunyai kedua faktor di atas yaitu kebiasaan yang tetap (Al Aadah) -cirikhasdarahhaidh (At Tamyiez), maka hendaklah berpedoman kepada kebiasaan tetap masa haidhnya. Hal ini sesuai dengan pendapat jumhur fuqaha, yakni Imam Ahmad, Abu Hanifah dan salah satu kecenderungan pendapat Asy Syafi'I rahimahullah. ${ }^{40}$

Dari kelima responden yang diteliti mereka menentukan habisnya haidh itu selain berdasarkan perhitungan hari juga melihat keadaan warna darah yang keluar kalau darah nya masih berwarna keruh (hitam campur putih). Mereka beranggapan hal itu masih haidh tetapi kalau sudah putih maka sudah suci. Hal ini sesuai dengan yang dikatakan oleh golongan Hanafiah dan Syafi'iyah yang mengatakan ia adalah haidh jika keluar pada hari haidh, yaitu sepuluh hari menurut Hanafiah dan lima belas hari menurut Syafi'iyah.

Adapun kebiasaan suci dari dua haidh dalam keadaan normal, haidh itu datang berulang setiap bulan, berulang kedatangan haidh setiap bulan itu disebut "daur" atau "siklus" haidh. Kedatangan haidh yang berulang itu tidaklah mesti tepat sekali dalam sebulan; walaupun memang teratur tiap-tiap 28 hari atau empat minggu, ditambah atau dikurang dua sampai tiga hari. Siklus haidh itu dihitung dari hari pertama tiap-tiap kedatangan haidh ${ }^{41}$.

Dari mahasiswa yang diteliti tidak ada seorangpun yang mengalami haidh normal setiap bulan mempunyai jangka yang sama. Kadangkadang ada yang mundur dan maju. Yang turut mempengaruhi adalah makanan, minuman dan kelelahan. Hal ini sesuai pula dengan penjelasan di atas pada saat penulis membicarakan faktor-faktor yang mempengaruhi usia haidh pertama.

Responden I yang pernah mengalami masamasa sucinya kurang dari lima belas (15) hari, dia

\footnotetext{
${ }^{40}$ M. Hasbi Ash Shiddieqy, 2002 Mutiara Hadits, (Jakarta : Bulan Bintang, 1955) hlm. 84.

${ }^{41}$ S. A. Gaelan, Arts, Ilmu Kebidanan, Jakarta : Balai Pustaka, 1957) jilid I, hlm. 34.
}

beranggapan yang keluar itu adalah istihadhah. Hal ini yang perlu diperhatikan bahwa, bila sudah terbiasa seorang wanita mengalami haidh hanya sehari semalam, maka sudah dipastikan dia mengalami masa suci selama 29 hari atau 28 hari, tinggal melihat beberapa hari hitungan atau bulannya.

Selanjutnya, dapat disimpulkan bahwa kebiasaan masa suci antara dua haidh adalah 24 atau 23 hari, dan masa suci yang paling sedikit antara dua haidh adalah 15 hari, sebab paling banyak haidh itu adalah 15 hari, jadi kalau dihitung pakai bulan maka masa suci tidak terlepas dengan masa haidhnya.

Adapun para responden yang mengetahui habisnya ialah itu dengan darah, perlu pula memperhatikan warna darah yang sering mereka alami, karena seorang wanita yang mengeluarkan darah haidh setelah sehari semalam atau sampai lima belas hari lima belas malam, maka semua darah yang keluar itu disebut sebagai darah haidh baik dalam bentuk satu warna (warna qawi saja) atau dua warna (warna qawi dan dhaif) dan kendatipun darah qawi keluar terlebih dahulu kemudian darah dhaif atau bahkan sebaliknya.

Bagi wanita yang keluar darah berupa darah yang berwarna qawi, dhaif maka darah tersebut disebut darah haidh, adapun yang warnanya adh'af disebut darah istihadhah, hal ini dengan persyaratan:

1. Darah warna qawi keluar mendahului dhaif.

2. Antara darah warna qawi dan dhaif tidak ada pemisah (warna lain).

3. Kumpulan darah berwarna qawi dan dhaif pada ketentuan waktu haidh, yakni tidak melebihi 15 hari 15 malam.

Akan tetapi, jika seorang wanita yang keluar darahnya secara berurutan, antara darah qawi, darah dhaif dan darah adh'af dan seterusnya asalkan tidak melebihi 15 hari 15 malam, maka semua darah itu disebut sebagai darah haidh.

Selanjutnya, dari ke lima responden yang diteliti mereka setelah melihat darah haidh sudah berhenti mereka tidak langsung mandi/bersuci, hal ini beralasan karena belum yakin dan dikhawatirkan bahwa kemungkinan darahnya itu bisa keluar lagi. Ada dua responden yang menundanya satu hari dan ada tiga responden yang dua hari. 


\section{Faktor dan Akibat Terjadinya Penundaan Bersuci Sehabis Haidh}

Dari hasil penelitian terhadap lima responden tersebut dapat diketahui bahwa dua orang responden yang menunda mandinya selama satu hari dan tiga orang responden yang menunda mandinya sampai dua hari. Dari hasil wawancara mereka memberikan alasan yang dapat dikatagorikan (1) Belum yakin, apakah darah haidhnya tidak keluar lagi, (2) Takut kalau darah haidhnya akan keluar lagi (3) Karena mau cepatcepat kuliah, jadi tidak sempat untuk melaksanakan mandi wajib. Dari ketiga faktor dan lama penundaan bersuci tersebut, untuk lebih jelasnya dapat dilihat dalam tabel berikut :

Tabel 1.

Faktor Penunda Sebera Bersuci dari Haidh

\begin{tabular}{clcc}
\hline No & Faktor Penundaan & F & Responden \\
\hline 1. & Belum yakin & 4 & $1,2,3,5$ \\
2. & Takut akan keluar lagi & 1 & 4 \\
3. & Mau kuliah & 2 & 3,5 \\
\hline
\end{tabular}

Tabel 2.

Lama Penundaan Bersuci dari Haidh

\begin{tabular}{cccc}
\hline No. & Lama Penundaan & F & Responden \\
\hline 1. & 1 (satu) hari & 2 & 4,5 \\
2. & 2 (dua) hari & 3 & $1,2,3$ \\
\hline
\end{tabular}

Akibat dari penundaan bersuci tersebut baik selama satu hari atau dua hari, kalau ternyata memang darah haidhnya tidak keluar lagi maka beberapa pembuatan ibadah yang seyogyanya dapat dilaksanakan tetap terhalang karena hadats pada dirinya belum terangkat, karena belum melaksanakan bersuci atau mandi wajib. Misalnya antara lain, yang seharusnya dapat mereka laksanakan adalah seperti shalat, puasa, membaca Al Qur'an menyentuh Al Qur'an, beri'tikaf. Apalagi kalau mereka menundanya sampai dua hari maka berapa waktu shalatnya akan tertinggal.

Dalam "Hikmatut Tasyri wal Filsafatub" juz I hal. 104 - 105 Al Haramain, oleh Al Ustadz Asy Syaikh Ali Ahmad Al Jurjawi, menjelaskan tentang hikmah mandi wajib. Dalam kitabnya beliau memaparkan bahwa sesungguhnya Allah Ta'ala menetapkan kewajiban mandi sesudah keluarnya mani, akan tetapi Dia tidak mewajibkannya sesudah keluarnya air kencing padahal kalau kita lihat sepintas bahwa keduanya keluar dari satu lubang yang sama dan anggota yang sama pula, dan sudah barang tentu mengandung hikmah yang tinggi dan rahasia yang menakjubkan.
1. Air kencing merupakan sesuatu yang tercipta dari sisa makanan dan minuman. Sedangkan mani adalah suatu materi yang terbentuk dari semua anggota badan, oleh karena itu bisa dilihat dan rasakan bahwa badan akan terpengaruh dengan keluarnya mani, sedangkan keluarnya air kencing tidak mempengaruhinya. Maka dengan mandi kekuatan yang sudah hilang tersebut akan pulih kembali. Apalagi kehilangan kekuatan dari badan bisa menyebabkan kemalasan dan tidak mampu melakukan ibadah menurut ketentuan yang ada, oleh karena itu Abu Dzarrin berkata: "Tatkala aku sudah mandi janabah seolab-olah aku sudah terbebas dari badan berat". Beban berat yang dimaksud adalah sebagai berikut:

a. Hilangnya rasa malas dari badan, sementara itu rasa malas merupakan beban berat.

b. Manusia apabila suci dari janabah sedangkan dia tidur umpamanya, maka nyawanya bisa naik ke alam yang tinggi dan dia akan bisa menyaksikan beberapa keanehan dan beberapa rahasia ciptaan Allah.

Darah haidh merupakan darah yang dihasilkan dari semua anggota badan wanita sebagaimana halnya sperma, oleh sebab itu mandi sesudah mampetnya haidh mengembalikan kekuatan yang hilang dari wanita.

2. Menghilangkan bau yang tidak sedap yang dapat membahayakan dirinya sendiri dan orang lain. Ketika ia mandi hilanglah segala apa yang dapat menimbulkan kejijikan dan melemahkan kesehatan.

3. Adapun mandi dari nifas, dapat menimbulkan dua faedah, yakni faedah hissiyah (indrawi) dan faedah ma'nawiyyah (spiritual). Faedah indrawi adalah hilangnya bau yang tidak sedap yang ditimbulkan oleh darah bersalin, sedangkan faedah spiritual adalah syukur kepada Allah yang telah menyelamatkannya dari bahaya melahirkan yaitu suatu bahaya yang sudah banyak diketahui oleh wanita.

\section{Tinjauan Hukum Islam tentang Menunda \\ Bersuci dari Haidh}

Dalam hasil penelitian ditemukan 3 faktor/ alasan yaitu untuk meyakinkan apakah haidhnya benar-benar sudah habis, takut kalau-kalau haidhnya keluar lagi, dan karena ingin cepat kuliah. Penundaan tersebut ada yang sampai dua hari, hal 
ini kalau ternyata darah haidhnya tidak ada lagi, maka beberapa waktu shalat yang mereka tinggalkan (bolehlah kita sebut meninggalkan dengan sengaja), padahal bagi orang yang berhenti haidh diperintahkan melaksanakan mandi atau bersuci.

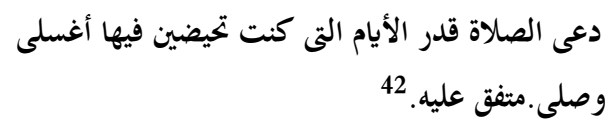

"Tinggalkanlah shalat selama hari-hari hadih itu, lalu mandilah dan sembahyanglah."

Kewajiban tersebut adalah wajib yang harus dilaksanakan merupakan tanda waktu-waktu tertentu, waktu tertentu tersebut merupakan tanda atas wajibnya melaksanakan suatu perintah, karena Allah telah mewajibkan waktu tertentu tersebut sebagai tanda yang menunjukkan atas wajibnya suatu perintah. Sebagaimana contoh: waktu shalat, apabila sudah masuk waktu maka menjadi tanda atas wajibnya melaksanakan shalat tersebut. Jika waktu Asar masuk maka wajiblah melaksanakan shalat Asar. Demikian juga bila Ramadhan telah tiba, maka wajiblah menjalankan puasa ${ }^{43}$. Berdasarkan uraian tersebut, maka apabila berhenti haidh, maka wajiblah ia bersuci. Selain itu juga untuk dapat melaksanakan ibadah yang terhalang oleh haidh. Adapun bagi mereka yang beralasan bahwa meyakinkan karena masih ragu-ragu, dalam qaidah ushul dikatakan:

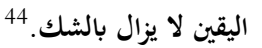

"Keyakinan itu tidak dapat dilahirkan dengan keragu-raguan".

Yang dimaksud dengan "yakin" adalah :

$$
\text { اليقين هو كان ثالنظر والدليل.45 }
$$

"Yakin ialah sesuatu yang tetap, baik dengan penganalisaan maupun dengan dalil".

Sedangkan yang dimaksud dengan syak adalah :

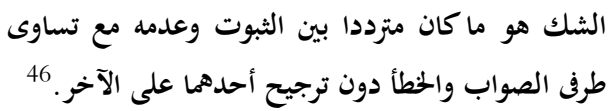

\footnotetext{
${ }^{42}$ Muhammad Ali bin Muhammad Asy Syaukani, Nailul Authar, (Mesir: Mushthafa al Baby al Halaby, Tth) hlm. 316.

${ }^{43}$ Lihat Ushul Figh, Prof. Muhammad Abu Zahrah, PT. Pustaka Firdaus, Terjemah oleh Saefullah Ma'shum, hlm. 34.

${ }^{44}$ Jalaluddin Abdurrahman As Sayuti, Al Asybab wan Nazhair, (Indonesia : Syirkah Nur Asia, Tth) hlm. 37.

45 Abdul Mudjib, AlQawaidhul Fiqhiyah, (Yogyakarta: Nur Cahaya, 1980) hlm. 25.

${ }^{46}$ Ibid., hlm. 26.
}

"Syak ialah sesuatu yang tidak menentu antara ada dan tiadanya dan dalam ketidak tentuan itu sama antara batas kebenaran dan kesalahan, tanpa dapat dimenangkan salah satunya".

Jadi keyakinan tidak dapat dihilangkan dengan keraguan, seperti seorang yang telah berwudhu dan ragu-ragu apakah ia sudah berhadats atau belum, maka ia dianggap masih mempunyai wudhu, karena mempunyai wudhu itu yang yakin, sedang berhadats masih diragukan. Maka, jika dikaitkan dengan masalah di atas, jika orang yang haidh itu belum yakin ia sudah suci (sudah habis haidh) atau takut kalau-kalau haidhnya akan keluar lagi, maka tidak mengapalah mereka meberi jarak waktu, akan tetapi penundaan itu tidak terlalu lama sekedar untuk meyakinkan saja.

Adapun penundaan yang sampai dua hari, apalagi jika ditambah alasan karena darurat sebab tidak sempat mandi pagi, karena kuliah pagi, maka dalam hal ini para ulama sebenarnya sependapat bahwa setiap sesuatu (benda, sikap atau perbuatan) yang mudaratnya (akibat buruk atau kesengsaraannya) lebih banyak daripada manfaat (faedahnya), baik terhadap individu, masyarakat sosial maupun segi keagamaan, maka hukumnya adalah terlarang (haram). Hal ini beralasan kepada hadits Rasulullah Saw yang diriwayatkan oleh Imam Malik, Imam Ahmad, Al Hakim, Al Baidhawy, Ad Daru Quthni dan Ibnu Majah yang berbunyi:

$$
\text { لاضرر ولا ضرار. }
$$

"Jangan membuat sengsara pada diri sendiri dan jangan (pula) membuat sengsara diri orang lain".

Akan tetapi, meskipun begitu, namun faktor mudarat oleh Jumhur Ulama tidaklah dijadikan patokan pertama di dalam menentukan hukum asal bagi sesuatu yang tidak ditemukan nash yang melarangnya. Faktor yang mudarat yang terdapat pada sesuatu (benda, sikap atau perbuatan) pada akhirnya memang ikut menentukan kepastian hukum, terlarang atau tidaknya sesuatu itu. Untuk ini, menurut hemat penulis, ada contoh dalam $\mathrm{Al}$ Qur'an, surat Al Baqarah ayat 219, yaitu ayat yang memberikan alasan diharamkannya minuman khamar dan perbuatan berjudi, yaitu :

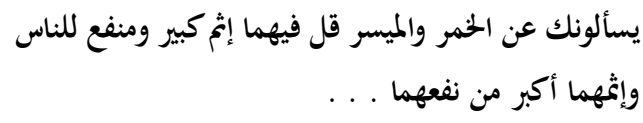

${ }^{47}$ Dr. Wahbah Az Zuhaily, Naz̧bariyatudh Dharurah Asy Syar'iyah, (Damasqus : Maktabah Al Faraby, 1969) hlm. 28. 
Dengan demikian bahwa setiap sesuatu (benda, sikap atau perbuatan) apabila faktor mudaratnya (akibat buruknya) lebih besar dari manfaatnya (faedah baiknya) baik terhadap individu, masyarakat sosial maupun segi keagamaan, maka hukumnya adalah terlarang (haram). Hal ini mengingat :

1. Firman Allah Swt. di dalam surah Al Baqarah 195 yang berbunyi :

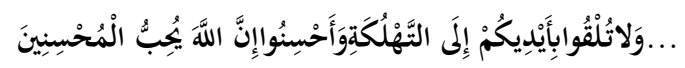

“... dan janganlah kamu menjatuhkan dirimu sendiri ke dalam kebinasaan, dan berbuat baiklah, karena sesungguhnya Allah menyukai orang-orang yang berbuat baik", ${ }^{48}$

2. Hadits Rasulullah Saw yang telah disebutkan dahulu yaitu:

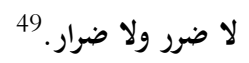

"Janganlah membuat darurat (sengsara) pada diri sendiri dan janganlah (pula membuat sengsara) dari orang lain."

Dari ayat dan hadits di atas timbullah sebuah kaidah ushul fiqh yang menjadi patokan, yakni  dilenyapkan. Adapun akibat dari penundaan mandi atau bersuci sehabis haidh tersebut maka beberapa perbuatan ibadah yang sebaiknya dapat dilaksanakannya menjadi terhalang misalnya saja ibadah shalat. Maka dari itu, jika penundaan bersuci itu karena alasan takut kalau darah haidhnya akan keluar lagi atau ditunda dahulu karena mau cepatcepat kuliah apalagi penundaan itu sampai 2 hari, maka hal tersebut beberapa waktu shalat yang ditinggalkannya, (karena seolah-olah meninggalkan shalat dengan sengaja).

Dalam hal ini para fuqaha sependapat bahwa orang yang terlupa dan tertidur, sehingga sembahyangnya tertinggal, diwajibkan mengqa-dha sembahyangnya.

Tetapi, timbul perbedaan pendapat mengenai orang yang bersengaja meninggalkan sembahyang, apakah wajib mengqadha sembahyang yang tertinggal. Dalam hal ini ada 2 pendapat.

\footnotetext{
${ }^{48}$ Departemen Agama RI., Al Qur'an dan Terjemahnya, (Jakarta : Proyek Pengadaan Kitab Suci Al Qur'an, 1979) hlm. 53.

${ }^{49}$ Ibid., hlm. 47.

50 Ali Hasaballah, Ushulut Tasyri' al Islamy, (Mesir : Darul Ma'arif, 1971) hlm. 379.
}

1. Pendapat berasal dari kalangan mazhab Syafi'i, Maliki, Hanbali dan Hanafi berpendapat orang yang bersengaja meninggalkan sembahyang wajib meng qadha sembah yangnya.

2. Pendapat yang berasal dari mazhab zhahiri Ibnu Hazm dan salah satu riwayat dari kasim dan wazir dari mazhab Syi'ah menyatakan orang yang meninggalkan sembahyang dengan bersengaja tidak wajib mengqadha sembahyangnya dan kalau juga mereka mengqadha sembahyangnya maka sembah yangnya dianggap tidak sah. ${ }^{51}$

Pendapat pertama yang mewajibkan qadha bagi orang yang bersengaja diperkuat dengan dalil :

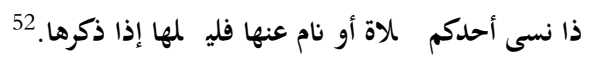

Jika salah seorang kamu lupa akan sesuatu sembahyang atau tertidur, maka hendaklah dia bersembahyang dikala dia ingat. (HR. Nasa'i, Abu Daud dan Turmudzi dari Abi Qatadah).

\section{من نسى لاة فلي لمها إذا ذكرها لا كفارة لها إلا ذلك. 53}

"Barang siapa lupa akan sesuatu sembahyang maka hendaklah dia menyembahyangkannya apabila dia telah ingat, tidak ada tebusan baginya (sembahyang) melainkan demikian”. (HR. Bukhari, Muslim dan Ahmad dari Anas bin Malik).

Dari pengertian hadits di atas yang mana Rasulullah memerintahkan kepada orang yang tertidur dan terlupa untuk mengqadha sembahyangnya, dengan cara kias lebih utama bagi mereka yang bersengaja, sebagaimana dikatakan oleh Dr. Wahbah :

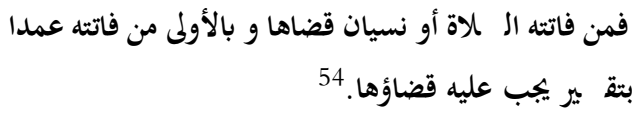

"Orang yang ketinggalan shalat karena tertidur atau terlupa wajib mengqadha, maka orang yang sengaja meninggalkan shalat lebih utama untuk diwajibkan mengqadhanya."

Begitu pula dikatakan tidak ada tebusannya melainkan dengan mengqadha, menunjukkan juga wajib qadha bagi orang yang bersengaja. Karena orang yang bersengaja berdosa dan lebih utama mereka menebus dosanya dari orang yang tidak berdosa. Pendapat ini diperkuat oleh hadits Rasulullah dari Jabir bin Abdullah :

\footnotetext{
51 Ibid.,

52 Prof. H. M. Asywadie Syukur, Lc., Perbandingan Mą̧̧ab, (Surabaya : PT. Bina Ilmu, 1994) hlm. 246.

53 As Sayyid Sabiq, op.cit., hlm. 90.

54 Ibid.
} 


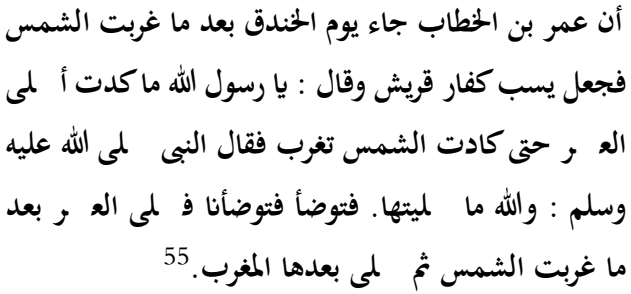

"Umar bin Khattab tiba pada hari pertempuran khandak sesudah hampir tenggelam matahari dan beliau sibuk menghadapi kafir Quraisy, beliau berkata: Hai Rasulullah, hampir saja aku tidak mengerjakan sembahyang Asar sampai matahari hampir tenggelam. Nabi bersabda : Demi Allah, akupun belum sembahyang (Asar), maka Rasulullah berwudhu dan kamipun berwudhu, beliau sembahyang Asar sesudah tenggelam matahari, kemudian sesudah itu beliau sembahyang Magrib”. (HR. Bukhari, Muslim dan Ahmad).

Hadits tersebut menerangkan bahwa Umar bin Khattab dan kaum muslimin, karena kesibukan menghadapi peperangan sehingga terlupa sembahyang dan mereka qadha sembahyang Asar pada waktu Maghrib. Oleh karena itu, kalau seandainya tidak wajib mengqadha sembahyang yang tertinggal, niscaya mereka tidak lagi mengerjakan sembahyang Ashar di luar waktu Asar. Dengan demikian, dapat disimpulkan bahwa jika penundaan itu disebabkan karena untuk meyakinkan maka sembahyangnya tidak diwajibkan diqadha, sesuai dengan hadits :

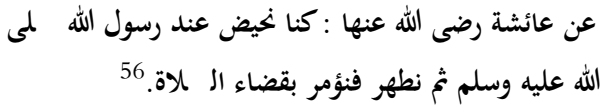

"Kami berhaidh pada masa Nabi Saw, kemudian kami bersuci lantas kami diperintah mengqadha shalat".

Akan tetapi apabila penundaan bersuci sehabis haidh itu dikarenakan kelalaian ataupun karena mau cepat-cepat kuliah, maka bagi mereka wajib mengqadha shalatnya. Dalam Fiqih Muyassar dijelaskan bahwa:

"Maka barang siapa yang meninggalkan shalat tanpa udzur niscaya ia benar-benar mendurhakai (maksiat) pada Allah Swt. dia telah berbuat sesuatu dosa besar dari beberapa dosa besar, maka ia wajib atasnya bertaubat pada Allah dan mengqadha shalat yang telah ia tinggalkan dengan segera". ${ }^{57}$

55 Dr. Wahbah Az Zuhaili, Al Fiqhul Islami wa Adillatuh, (Damasqus, Darul Fikri, 1989), cet III, juz II, hlm. 131.

${ }^{56}$ Imam Al Bukhari, Matan Al Bukhari, (Semarang: Thoha Putra, 1981) jilid I, hlm. 147.

57 Syekh Ahmad Isa Asyur, Al Fiqhul Muyassar fil Ibadah, (Darul Fikri, 1981) hlm. 263.

\section{Kesimpulan}

Dari uraian terdahulu dapatlah disimpulkan bahwa haidh adalah darah yang keluar dan berasal dari dalam Rahim wanita sehat, yang lain dari kelanjutan peristiwa bersalin, yang kejadian pertamanya menjadi pertanda awal baligh (sampai umur) dan merupakan peristiwa kebiasaan atas kaum wanita secara berulang selama beberapa hari setiap bulan.

Para ulama telah sepakat berpendapat sebagai ijma' bahwa peristiwa haidh adalah menjadi penghalang sholat, puasa, thawaf secara mutlak. Kebanyakan (jumhur) ulama berpendapat bahwa haidh juga penghalang terhadap ibadah I'tikaf di dalam masjid dan ibadah membaca ayat-ayat alQur'an (kecuali sebagai do'a). Sehubungan dengan tersebut di atas apabila terjadi penundaan bersuci/ mandi, maka hal tersebut tidak bisa dilaksanakan.

Dalam eksplorasi yang dilakukan pada tiaptiap responden, alasan penundaan yang ditemui dari lima kasus adalah diantaranya: karena untuk meyakinkan apakah haidh nya sudah benar-benar berhenti. (kasus 1,2,3 dan 5), karena takut kalau darah haidh akan keluar lagi. (kasus 4), dan karena mau pergi kuliah. (kasus 3 dan 5). Menyangkut alasan-alasan penundaan ini, menurut pandangan hukum Islam, jika alasan untuk meyakinkan maka diperbolehkan saja asal tidak melebihi dari 1 hari. (kasus 2,3 dan 5). Tetapi kalau alasan mau pergi kuliah, maka hal ini tidak dibenarkan karena sudah termasuk melalaikan dan wajib baginya untuk mengqadha shalatnya. (kasus 3 dan 5).

\section{Saran-Saran}

Dari hasil penelitian ini, sugesi yang dapat disampaikan kepada para wanita yang sudah mengalami haidh diantaranya, agar mengetahui/ mengenali bilangan hari dan warna darah yang keluar dalam setiap bulannya. Selain itu, hendaknya wanita yang sudah mengalami haidh mempersiapkan segala sesuatunya untuk keperluan bersuci /mandi sebelum akan melaksanakannya, jika telah mengetahui kapan habisnya haidh menurut kebiasannya setiap bulan. Terakhir,bagi wanita yang pernah mengalami jarak antara dua haidh kurang dari 15 hari, maka disarankan untuk berdiskusi dengan ahli medis untuk memeriksakan diri mengenai permasalahan haidhnya. 


\section{Daftar Kepustakaan}

Abdul Wahab Abdul Lathif, Mukbtarat al Abadits wal Hikaman Nabawiyah, Mushthafa al Baby al Halaby, Mesir, $1378 \mathrm{H}$.

Abdul Mudjib, Al-Qawaidul Fiqhiyah, Nur Cahaya, Yogyakarta, 1980.

Abdul Baqi, Muhammad Fuad, Al Lu'lu' wal Marjan, jilid I, Daru Ibni Huzaimah, Ar Riyadh, $1414 \mathrm{H}$.

Abu Zahrah Muhammad, Prof., Ushul al Fiqh, penterjemah Saefullah Ma'shum, PT. Pustaka Firdaus, Jakarta, 1994.

Asqalani, Al Hafizh Ibnu Hajar Al, Buluqbul Maram min Adillati LAbkam, Maktabah at Tijariah al Kubra, Mesir, $1352 \mathrm{H}$.

As Sayuthi, Jalaluddin Abdurrahman, Al Asybah wan Ną̧hair, Syirkah Nur Asia, Indonesia, Tth.

Asywadie Syukur, Prof., H.M., Perbandingan Maz̧bab, PT. Bina Ilmu, Surabaya, 1994.

Bukhari, Imam, Matan al Bukhari, Thoha Putra, Semarang, 1981.

Dapertemen Agama RI., Al Qur'an dan Terjemah nya, Proyek Pengadaan Kitab Suci AlQur'an, Jakarta, 1979.

Gaelan, Arts, S.A., IlmuKebidanan, Balai Pustaka, Jakarta, 1957.

Hasaballah, Ali, Ushulut Tasyri' al Islamy, Darul Ma’arif, Mesir, 1971.

Ibrahim Anis, Dr. et. al, Al Mu'jamul Wasith, Darul Ma’arif, Mesir, 1972.

Ibrahim Muhammad al Jamal, Fighul Mar'atil Muslimah, penterjemah Zaid Husain al Hamid, Pustaka Amani, Jakarta, 1995.
Isa Asyur, Syekh Ahmad, Al Fiqhul Muyassar fil Ibadah, Darul Fikri, 1981.

Jashshash, Abu Bakar Ahmad Ibnu Ali Al, Abkamul Qur'an, Darul Mushhaf, cairo, Tth.

Makky, Abu Bakar Al, I'anatuth Thalibin, Mushthafa al Baby al Halaby, Mesir, Tth.

MuhlishUsman, Drs., H. M.A., Kaidah-kaidah Usbuliyah dan Fiqhiyah, PT. Raja Grafindo Persada, Jakarta, 1996.

Nisabury, Abul Husain Muslim bin Al Hajjaj bin Muslim Al Qusyairy, An, Al Jami' us Shabih, Darul Fikri, Beirut, Tth.

Qurthuby, Abdul Walid Muhammad bin Ahmad Ibnu Rusyd Al, Bidayatul Mujtabid wa Nihayatul Muqtashid, Mushthafa al Baby al Halaby, Mesir, 1960.

Sallam Madkur, Dr. Muhammad, Al Islam wal Usrah wal Mujtama, Darun Nahdhah al Arabiyah, Cairo, 1968.

Sabiq, As Sayyid, Fiqhus Sunnah, Darul Kitab al Araby, Beirut, 1973.

Shan'any, Muhammad bin Ismail Al Kahlany Ash, Sublus Salam, Mushthafa al Baby al Halaby, Mesir, 1960.

Shiddieqy, M. Hasbi, Ash, 2002 Mutiara Hadits, Bulan Bintang, Jakarta, 1955.

Syaukani, Muhammad Ali bin Muhammad Asy, Nailul Authar, Mushthafa al Baby al Halaby, Mesir, Tth.

Zuhaili, Dr. Wahbah, Az, Al Wasith Usbulil Fiqhil Islamy, Darul Fikri, Beirut, 1969. 